\title{
APLIKASI AKUNTANSI BERBASIS ANDROID DAN GAMBARAN PROFIL UMKM PENGGUNA POTENSIAL MENGGUNAKAN IFLS DATA
}

\author{
Irena Paramita Pramono \\ Universitas Islam Bandung \\ irena.paramita@gmail.com
}

\section{Riyang Mardiani}

Universitas Islam Bandung

riyang.mardini@gmail.com

\author{
Asri Suangga \\ Universitas Islam Bandung \\ asri.suangga@gmail.com
}

\author{
Muhammad Jefriendy Ilhamsyah \\ Universitas Islam Bandung \\ jefriendy16@gmail.com
}

\begin{abstract}
Although Micro, Small and Medium Enterprises (MSMEs) are the main pillars of in Indonesia's economy, MSMEs often have difficulties in preparing a good financial reporting. MSMEs disability to provide good financial reports will affect the inability of investors and creditors to assess the financial performance of MSMEs. Digitalisation is helpful for MSMEs to provide convenience for financial transactions recording with the emergence of various accounting applications based on Android. Therefore, this study was conducted to provide an overview of what accounting applications can be used by MSMEs that can be downloaded freely at the Google Play Store, as well as provide a description of any MSME profiles that have the potential intensity of using such accounting applications in terms of intensity of use mobile and internet in the implementation of its business. This research was conducted using inductive reasoning, with observations and surveys as data collection methods. Literature studies and observations were conducted to examine android-based accounting applications circulating in the community which freely downloaded in google play store. While descriptive statistics are presented to determine the profile of MSMEs that have the potential to use accounting-based applications based on the intensity of the use of mobile phones and the internet in business operations. This data was processed using secondary data from the Indonesian Family Life Survey (IFLS) 5 in 2015 by RAND.
\end{abstract}

Keywords: Accounting, Application, Android Base, MSME

\begin{abstract}
Abstrak
Usaha Mikro, Kecil, dan Menengah (UMKM) merupakan usaha yang menjadi penopang utama perekonomian di Indonesia. UMKM seringkali kesulitan dalam melakukan pelaporan keuangan yang baik. Ketidakmampuan UMKM dalam menyediakan laporan keuangan yang baik akan berdampak ketidakmampuan investor dan kreditor dalam menilai kinerja keuangan UMKM. Digitalisasi menjadi sebuah potensi bagi UMKM menyediakan kemudahan untuk mencatat transaksi keuangan dengan munculnya berbagai aplikasi akuntansi yang berbasis android. Oleh karena itu, penelitian ini dilakukan untuk menyediakan gambaran mengenai aplikasi akuntansi apa saja yang dapat digunakan oleh UMKM yang dapat didownload secara bebas di google play store, serta menyediakan deskripsi profil UMKM apa saja yang memiliki intensitas yang potensial menggunakan aplikasi akuntansi tersebut dilihat dari intensitas penggunaan handphone dan internet dalam pelaksanaan usahanya. Penelitian ini dilakukan dengan menggunakan penalaran induktif, dengan metode penyajian deskripsi serta observasi dan survey untuk metode pengumpulan datanya. Studi literatur dan observasi dilakukan untuk mengkaji terkait aplikasi akuntansi berbasis android yang beredar di masyarakat. Sedangkan statistik deskriptif disajikan dengan untuk mengetahui profil UMKM yang berpotensi menggunakan aplikasi akuntansi berbasis dilihat dari intensitas penggunaan handphone dan internet dalam pelaksanaan usaha. Data ini diolah dengan menggunakan data sekunder dari survey Indonesian Family Life Survey (IFLS) 5 pada tahun 2015 oleh RAND.
\end{abstract}

Kata Kunci: Aplikasi, Akuntansi, Basis Android, UMKM 


\section{Pendahuluan}

\subsection{Latar Belakang Masalah}

Usaha Mikro, Kecil, dan Menengah (UMKM) merupakan usaha yang menjadi penopang utama perekonomian di Indonesia. UMKM menyerap 97\% dari total tenaga kerja di Indonesia, dan menyumbang lebih dari 57\% total GDP pada tahun 2015 (Bank Indonesia, 2015). Namun, perkembangan UMKM bukan tanpa kendala. Bank Indonesia (BI) mencatat hanya $30 \%$ dari total UMKM yang memiliki akses pada fasilitas keuangan. Selain masalah collateral assets yang biasanya diminta oleh pihak bank, UMKM juga menghadapi kesulitan dalam melakukan pelaporan keuangan yang baik. Ketidakmampuan UMKM dalam menyediakan laporan keuangan yang baik akan berdampak pada ketidakmampuan mereka menghitung pendapatan dan pajak secara tepat. UMKM di Indonesia, mempunyai standar pelaporan keuangan khusus yang dibuat IAI (Ikatan Akuntan Indonesia) yang dinamanakan Standar Akuntansi Keuangan untuk Entitas Mikro, Kecil dan Menengah (SAK EMKM) sejak Januari 2018. PSAK EMKM ini penting untuk menyediakan standar pelaporan keuangan sesuai dengan International Financial Reporting Standard (IFRS) namun dengan beberapa penyederhanaan, agar laporan keuangan tersebut tetap dapat diaudit jika diperlukan. Namun pada penelitian sebelumnya oleh Rudiantoro dan Siregar (Rudiantoro, 2012) mengungkapkan masih rendahnya kualitas laporan keuangan UMKM yang berakibat pada diragukannya relevansi dan keandalan dari laporan tersebut oleh perbankan.

Menjelang periode Revolusi Industri 4.0. dimana tren otomasi terjadi pada semua bidang, bidang akuntansi dan UMKM merupakan salah satu bidang yang terkena dampak signifikan dari perkembangan teknologi saat ini. Kemudahan di era digital menjadi sebuah potensi bagi UMKM untuk lebih berkembang, baik dari segi perluasan pangsa pasar, kemudahan bertransaksi keuangan maupun kemudahan untuk mencatat transaksi keuangan secara digital. Kemudahan mencatat transaksi keuangan maupun menyediakan laporan keuangan secara digital disediakan juga oleh berbagai aplikasi atau software akuntansi yang disediakan di internet baik yang berbasis desktop maupun yang berbasis cloud computing, baik yang gratis maupun yang berbayar. Aplikasi akuntansi berpotensi menyediakan kemudahan bagi UMKM untuk menyediakan laporan keuangan yang baik dan sesuai dengan standar EMKM. Tercatat lebih dari 54\% penduduk Indonesia telah terkoneksi dan menggunakan internet menurut Asosiasi Penyelenggara Jasa Internet Indonesia (Asosiasi Penyelenggara Jasa Internet Indonesia, 2018). Penggunaan handphone di masyarakat juga sangat tinggi, tercatat sebanyak 371,4 juta ponsel terdaftar atau 142\% dari total populasi (databooks, t.thn.). Oleh karena itu, kesulitan UMKM dalam menyediakan laporan keuangan yang berkualitas, hendaknya dapat difasilitasi oleh teknologi. 


\subsection{Identifikasi Masalah}

Pentingnya UMKM dalam menyediakan laporan keuangan yang andal dan relevan serta kesulitan dalam proses penyediaan laporan keuangan tersebut, hendaknya dapat dijembatani oleh teknologi. Aplikasi akuntansi berbasis android merupakan salah satu penerapan teknologi yang memiliki potensi untuk mengintermediasi kesulitan dari UMKM dan kebutuhan dari berbagai pihak terkait penyediaan laporan keuangan UMKM yang berkualitas, relevan dan andal. Namun dengan banyaknya aplikasi akuntansi yang beredar di masyarakat bisa dibayangkan pelaku usaha yang boleh jadi tidak mengetahui seluk beluk proses akuntansi menjadi kewalahan dalam menentukan aplikasi akuntansi apa yang tepat bagi jenis usaha mereka. Oleh karena itu, penelitian ini dilakukan untuk memberikan deskripsi pilihan aplikasi akuntansi apa saja yang dapat digunakan oleh UMKM. Beberapa penelitian sebelumnya juga telah menyebutkan beberapa kesulitan yang dihadapi oleh UMKM dalam penggunaan berbagai aplikasi tersebut. Oleh karena itu diperlukan informasi mengenai profil UMKM yang memiliki potensi untuk menggunakan teknologi aplikasi akuntansi berdasarkan dari intensitas pemakaian handphone dan internet dalam pelaksanaan kegiatan usaha UMKM.

\subsection{Tujuan Penelitian}

Secara terperinci, tujuan penelitian ini dijabarkan sebagai berikut:1) Menyediakan informasi mengenai aplikasi akuntansi berbasis android yang beredar di masyarakat dan aplikasi akuntansi apa saja yang dapat digunakan oleh UMKM; 2) Memberikan gambaran atau deskripsi terhadap profil UMKM yang berpotensi menggunakan aplikasi akuntansi di Indonesia berdasarkan IFLS data.

\subsection{Manfaat Penelitian}

Penelitian ini dilakukan untuk menyediakan informasi pada UMKM mengenai pilihan aplikasi akuntansi apa saja yang bisa didownload pada aplikasi google playstore. Selanjutnya, pengajar akuntansi pada tingkat universitas yang memiliki kewajiban Pengabdian Kepada Masyarakat (PKM) hendaknya menjadi partner dari UMKM dalam menyediakan pendidikan untuk menyediakan laporan keuangan yang berkualitas. Data profil UMKM yang berpotensi menggunakan aplikasi akuntansi di Indonesia diharapkan dapat memberikan gambaran kepada para pengajar dalam menentukan prioritas UMKM yang mendapat pendampingan dalam pembuatan laporan keuangan dengan menggunakan aplikasi akuntansi berbasis android.

\section{Landasan Teori}

\subsection{Usaha Mikro, Kecil dan Menengah}

Pengertian Usaha Mikro dan Kecil (UMK) dijelaskan dalam UU No. 20 tahun 2008 tentang UMK. Usaha mikro adalah usaha produktif milik orang perorangan dan/atau badan usaha perorangan yang memenuhi kriteria, yaitu aset yang dimiliki usaha tersebut kurang atau sama dengan $\mathrm{Rp}$ 50.000.000,00 (lima puluh juta rupiah) dan hasil penjualan tidak lebih dari Rp 300.000.000,00 (tiga 
ratus juta rupiah). Sedangkan usaha kecil adalah usaha ekonomi produktif yang berdiri sendiri, yang dilakukan oleh orang perorangan atau badan usaha yang bukan merupakan anak perusahaan atau bukan cabang perusahaan yang dimiliki, dikuasai, atau menjadi bagian baik langsung maupun tidak langsung dari Usaha Menengah dan Besar (UMB) dan yang memenuhi kriteria yaitu aset yang dimiliki lebih dari Rp 50.000.000,00 (lima puluh juta rupiah) - Rp500.000.000,00 (lima ratus juta rupiah) dan hasil penjualan lebih dari $\mathrm{Rp} 300.000 .000,00$ (tiga ratus juta rupiah) Rp2.500.000.000,00 (dua milyar lima ratus juta rupiah). Sedangkan Usaha Menengah adalah jenis usaha yang memiliki aset lebih dari 500 juta rupiah hingga 10 milyar rupiah tidak termasuk tanah dan bangunan tempat usaha; atau memiliki hasil penjualan tahunan lebih dari 2,5 miliar rupiah sampai 50 milyar rupiah (Kementerian Koperasi dan UKM, 2008).

Laporan TNP2K (Burger, 2015) menyebutkan berdasarkan aspek komoditas yang dihasilkan, UMKM juga memiliki karakteristik antara lain: a) kualitas produk belum standar; b) desain produk terbatas; c) jenis produk terbatas; d) kapasitas dan daftar harga produk terbatas; e) bahan baku kurang terstandar; f) kontinuitas produk tidak terjamin dan kurang sempurna. Lebih lanjut, laporan TNP2K menjelaskan kendala atau hambatan yang sering muncul dalam UMKM dibagi menjadi 2, yaitu kendala internal dan kendala eksternal:

Tabel 2.1. Kendala UMKM

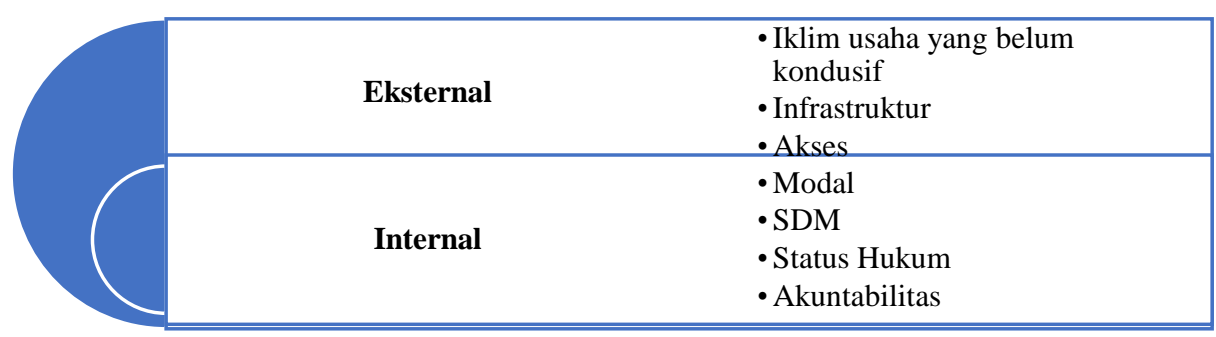

Sumber:TNP2K report (Bank Indonesia, 2015)

Salah satu masalah internal yang dihadapi UMK adalah masalah akuntabilitas. Masalah akuntabilitas ini terjadi karena UMK belum memiliki sistem administrasi manajemen dan keuangan yang baik. Akuntabilitas UMK yang kurang baik salah satunya disebabkan tidak adanya pemisahan kepemilikan di antara pemilik UMK dan entitas UMK. Presentasi akuntabilitas UMK yang kurang baik akan mengakibatkan pihak bank sulit mengidentifikasi informasi usaha secara lengkap dan UMK tersebut menjadi sulit mengakses modal dan investasi dari pihak luar.

\subsection{Aplikasi Akuntansi}

Akuntansi adalah salah satu bidang yang terkena dampak dahsyat dari perkembangan teknologi. Dampak yang paling dapat dirasakan tentu saja adalah pemrosesan data yang tadinya menggunakan sistem manual berubah menjadi sistem komputer dan pelaporan keuangan yang bisa dilakukan secara real time. Selain mempermudah kinerja seorang akuntan, perkembangan teknologi 
akan membuka peluang besar bagi para akuntan untuk berperan dalam bidang akuntansi baik dari segi perancangan sistem, pemakai maupun sebagai pemeriksa (auditor). Besarnya kebutuhan UMK untuk menyediakan laporan keuangan berkualitas, dengan tetap mempertimbangkan faktor biaya dan efesiensi, maka aplikasi atau layanan penyedia sistem akuntansi baik yang berbasis komputer maupun cloud banyak berkembang saat ini.

Aplikasi akuntansi yang beredar saat ini sudah sangat banyak, ada yang berbasis cloud computing dan ada pula yang berbasis desktop. Software atau aplikasi akuntansi yang berbasis desktop adalah software akuntansi yang melakukan penyimpanan database di storage lokal. Sedangkan software akuntansi berbasis cloud computing adalah software akuntansi yang menyimpan database dan komputasinya di server cloud atau internet (Anitasari, 2017). Sedangkan aplikasi akuntansi yang menjadi fokus pada penelitian ini adalah software akuntansi yang dapat dijalankan di smartphone baik yang berbasis desktop maupun cloud computing.

Aplikasi dalam bentuk software dapat dikelompokkan menjadi 2, yaitu system software dan application software (O'Brien, 2010). Pada system software adalah jenis software yang digunakan untuk menjalankan hardware komputer dan diinstal ketika sistem operasi diinstal. Dan pada system software, ketika sebuah perangkat dinyalakan, maka program itu akan terus dijalankan. Sedangkan pada application software, program ini hanya berjalan ketika diminta dan dijalankan dengan tujuan khusus untuk melakukan tugas tertentu. Aplikasi akuntansi berbasis android adalah jenis application software yang dijalankan pada jenis perangkat smartphone.

\subsection{Penelitian Terdahulu}

UMKM sejak 1 Januari 2018 telah memiliki standar pelaporan keuangan khusus yang dibuat IAI (Ikatan Akuntan Indonesia) yang dinamanakan Standar Akuntansi Keuangan untuk Entitas Mikro, Kecil dan Menengah (SAK EMKM). Standar ini digunakan untuk UMKM yang belum memiliki kapasitas untuk menyediakan Standar Akuntansi Keuangan Entitas Tanpa Akuntabilitas Publik (SAK ETAP). Penelitian yang dilakukan oleh Rudiantoro dan Siregar (Rudiantoro, 2012) menyatakan bahwa implementasi SAK ETAP terhadap peningkatan kualitas laporan keuangan sampai sejauh ini menghadapi kendala akibat masih rendahnya pemahaman para pengusaha UMKM atas SAK ETAP. Penelitian lain yang dihasilkan oleh Narsa, Widodo dan Kurnianto (Narsa, 2012) juga menyatakan hal yang sama bahwa UMKM memiliki kendala dalam menerapkan SAK ETAP antara lain: 1) Tidak adanya catatan transaksi yang baik dan tertib; 2) Ketidakpahaman pelaku UMKM mengenai bentuk catatan transaksi itu seperti apa; 3) munculnya persepsi bahwa catatan keuangan adalah suatu hal yang rumit; 4) persepsi bahwa tanpa laporan keuangan yang baik, proses usaha tetap berjalan. Penelitian oleh Anggraeni (Anggraeni, 2016) terhadap UMKM menunjukkan bahwa pemilik usaha hanya sebatas mencatat kegiatan penerimaan dan pengeluaran keuangan tanpa disertai dokumen pendukung. Kendala UMKM dalam menyediakan laporan keuangan secara garis besar disebabkan karena tidak adanya sebuah sistem yang mudah yang mendorong UMKM untuk mencatat laporan keuangan. 
Kemudahan akses dan penggunaan aplikasi akuntansi, menjadi sangat penting karena akan memberikan kesempatan bagi UMKM mengurangi biaya atau cost yang biasanya muncul dari proses pembuatan laporan keuangan.

Beberapa penelitian terdahulu terkait dengan kualitas sistem informasi akuntansi disajikan oleh Susanto, pada penelitian tersebut dinyatakan bahwa kualitas informasi akuntansi sangat dipengaruhi oleh sistem informasi akuntansi (Susanto, 2015). Kemudian riset yang dilakukan oleh Fitrios menyebutkan bahwa manajemen pada tingkat atas dan pelatihan pengguna sangat berpengaruh terhadap implementasi sistem informasi akuntansi pada rumah sakit tipe A,B dan C di Provinsi Riau (Fitrios, 2016). Riset oleh Iskandar menemukan komitmen manajemen dan kompetensi pengguna mempengaruhi kualitas sistem informasi (Iskandar, 2015). Berdasarkan dari hasil riset di atas, terlihat bahwa keberhasilan dari dijalankannya sebuah sistem infomasi akuntansi dipengaruhi oleh beberapa hal, termasuk pada terlatihnya pengguna dan kompetensi pengguna. Oleh karena itu, penting untuk memetakan pengguna potensial dalam penggunaan aplikasi akuntansi oleh UMKM. Namun, masih terdapat beberapa tantangan yang dihadapi oleh UMKM dalam menggunakan aplikasi akuntansi, terutama familiaritas terhadap penggunaan teknologi. Karena familiaritas terhadap penggunaan teknologi tentu akan berdampak pada kemampuan UMKM dalam menggunakan aplikasi tersebut.

\section{Metode Penelitian}

Penelitian ini dilakukan dengan menggunakan penalaran induktif, dengan metode penyajian deskripsi serta observasi dan survey untuk metode pengumpulan datanya. Studi literatur dan observasi dilakukan untuk mengkaji terkait aplikasi akuntansi berbasis android yang beredar di masyarakat. Sedangkan statistik deskriptif disajikan dengan untuk mengetahui profil UMKM yang berpotensi menggunakan aplikasi akuntansi berbasis dilihat dari intensitas penggunaan handphone dan internet dalam pelaksanaan usaha. Data ini diolah dengan menggunakan data sekunder dari survey Indonesian Family Life Survey (IFLS) 5 pada tahun 2015 oleh RAND.

Indonesian Family Life Survey (IFLS) adalah merupakan survei yang dilakukan secara berkelanjutan oleh RAND terhadap rumah tangga di Indonesia. IFLS telah dilakukan sebanyak 5 kali di Indonesia, IFLS 1 diadakan pada tahun 1993/1994 bekerjasama dengan Lembaga Demografi Universitas Indonesia. Berlanjut dengan IFLS 2 diadakan pada tahun 1997/1998 yang berkolaborasi dengan UCLA dan Lembaga Demografi Universitas Indonesia. Selanjutnya IFLS 3 dilakukan pada tahun 2000 berkolaborasi dengan Pusat Penelitian Populasi Universitas Gadjah Mada (UGM). IFLS 4 diadakan pada tahun 2007/2008 bekerjasama dengan CPPS UGM dan Survey Metre, dan IFLS diadakan pada tahun 2014-2015. Data yang digunakan pada penelitian ini adalah data pada IFLS 5 yang diadakah pada tahun 2014-2015. Sampel survei ini adalah perwakilan dari 83\% populasi Indonesia dan terdiri dari 30.000 individu yang tinggal di 13 provinsi dari total 27 provinsi pada waktu itu. Survei IFLS 5 pada tahun 2015 dilakukan pada 15.921 rumah tangga yang terletak di 13 
provinsi di Indonesia. Berdasarkan pada data tersebut terdapat 5.759 rumah tangga yang memiliki usaha non pertanian yang akan menjadi objek penelitian. Penelitian ini menggunakan program STATA 14 dalam kegiatan analisisnya.

\section{Hasil dan Diskusi}

\subsection{Aplikasi Akuntansi Berbasis Android}

Berdasarkan hasil observasi terhadap aplikasi akuntansi yang ditemukan oleh tim peneliti, terdapat 14 aplikasi akuntansi berbasis android yang bisa digunakan oleh UMKM dalam pembuatan laporan keuangannya beserta rating:

Tabel 4.1. Daftar Aplikasi Akuntansi untuk UMKM

\begin{tabular}{|c|c|c|c|c|c|c|}
\hline No. & Nama Aplikasi & Rating & $\begin{array}{l}\text { Tanggal } \\
\text { Rilis }\end{array}$ & Developer & $\begin{array}{l}\text { Jumlah } \\
\text { Download }\end{array}$ & Bahasa \\
\hline 1 & $\begin{array}{l}\text { Akuntansi UKM } \\
\text { WiinFeel }\end{array}$ & Rating 3+ & $09 / 12 / 2014$ & $\begin{array}{l}\text { WiinFeel, } \\
\text { Swasta }\end{array}$ & $\begin{array}{l}\text { 100.000+Do } \\
\text { wnloaded }\end{array}$ & Indonesia \\
\hline 2 & $\begin{array}{l}\text { Lamikro- } \\
\text { Akuntansi } \\
\text { Usaha Mikro }\end{array}$ & Rating 3+ & 05/01/2018 & $\begin{array}{l}\text { Deputi Bidang } \\
\text { Pengembangan } \\
\text { SDM- } \\
\text { Kementrian } \\
\text { KUKM RI }\end{array}$ & $\begin{array}{l}\text { 10.000+Do } \\
\text { wnloaded }\end{array}$ & Indonesia \\
\hline 3 & $\begin{array}{l}\text { Akuntansi } \\
\text { Keuangan }\end{array}$ & Rating 3+ & $18 / 10 / 2018$ & AppIndoDev2 & $\begin{array}{l}\text { 50.000+Don } \\
\text { wload }\end{array}$ & Indonesia \\
\hline 4 & SI APIK & Rating 3+ & $18 / 01 / 2016$ & $\begin{array}{l}\text { Bank } \\
\text { Indonesia }\end{array}$ & $\begin{array}{l}50.000+\text { Don } \\
\text { wload }\end{array}$ & Indonesia \\
\hline 5 & $\begin{array}{l}\text { Pembukuan \& } \\
\text { Akuntansi. } \\
\text { Stock Barang. } \\
\text { Arus Kas }\end{array}$ & Rating 3+ & 08-Feb-19 & 1C-Rarus Ltd & $\begin{array}{l}\text { 100.000+Do } \\
\text { wnloaded }\end{array}$ & Indonesia \\
\hline 6 & $\begin{array}{l}\text { Book Keeper } \\
\text { Accounting, } \\
\text { GST Invoicing, } \\
\text { Inventory }\end{array}$ & Rating 3+ & 08-Mar-19 & $\begin{array}{l}\text { Just Apps } \\
\text { Pvt.Ltd }\end{array}$ & $\begin{array}{l}\text { 500.000+Do } \\
\text { nwload }\end{array}$ & Inggris \\
\hline 7 & $\begin{array}{l}\text { Xero } \\
\text { Accounting } \\
\text { Software }\end{array}$ & Rating 3+ & 01-Okt-12 & $\begin{array}{l}\text { Xero } \\
\text { Accounting }\end{array}$ & $\begin{array}{l}\text { 500.000+Do } \\
\text { nwload }\end{array}$ & Inggris \\
\hline 8 & Akuntansi & Rating 3+ & $07-A g u-16$ & Gookkis & 1000+Donw & Indonesia \\
\hline
\end{tabular}




\begin{tabular}{|l|l|l|l|l|l|l|}
\hline 9 & Dagang - Beta & & & Studio & load & \\
\hline 9 & Zahir Simply & Rating 3+ & 26-Jan-18 & $\begin{array}{l}\text { Zahir } \\
\text { Internasional }\end{array}$ & $\begin{array}{l}10.000+\text { Do } \\
\text { wnloaded }\end{array}$ & Indonesia \\
\hline 10 & $\begin{array}{l}\text { Grow - } \\
\text { Akuntansi \& } \\
\text { Keuangan UKM }\end{array}$ & Rating 3+ & 20-Agu-18 & $\begin{array}{l}\text { Mid Solusi } \\
\text { Nusantara, PT }\end{array}$ & $\begin{array}{l}1.000+\text { Don } \\
\text { wload }\end{array}$ & Indonesia \\
\hline 11 & $\begin{array}{l}\text { Accounting } \\
\text { Invoicing - } \\
\text { OneUp }\end{array}$ & Rating 3+ & 22-Apr-15 & ONE UP & $\begin{array}{l}50.000+\text { Don } \\
\text { wload }\end{array}$ & Inggris \\
\hline 12 & $\begin{array}{l}\text { Free GST } \\
\text { Invoice Billing } \\
\text { Stock Inventory } \\
\text { Accounts }\end{array}$ & Rating 3+ & 08-Feb-16 & Solutions & $\begin{array}{l}\text { nwload } \\
\text { Vyapar Tech }\end{array}$ & Inggris \\
\hline 13 & $\begin{array}{l}\text { Catatan } \\
\text { Keuangan Usaha }\end{array}$ & Rating 3+ & 03-Mar-18 & PucungDev & $\begin{array}{l}\text { } \\
\text { wnloaded }\end{array}$ & \\
\hline 14 & $\begin{array}{l}\text { Pencatat } \\
\text { Keuangan }\end{array}$ & Rating 3+ & 30-Mei-13 & Alamsz Inc & $\begin{array}{l}100.000+\text { Do } \\
\text { wnloaded }\end{array}$ & Indonesia \\
\hline
\end{tabular}

Sumber: diolah dari berbagai sumber

Aplikasi yang terdaftar pada tabel di atas adalah beberapa aplikasi berbasis android yang bisa digunakan oleh UMKM yang bisa didownload dengan bebas pada aplikasi google play store. Semua aplikasi tersebut memiliki nilai rating $3+$ berdasarkan dari akumulasi nilai rating yang diberikan oleh penggunanya. Tahun pengembangan aplikasi-aplikasi ini juga cukup beragam, ada yang sudah dikembangkan sejak tahun 2012, ada pula yang baru dikembangkan pada bulan Maret 2019. Dengan jumlah download berkisar antara 1.000 - 500.000 download. Developer dari aplikasi ini juga beragam, ada yang berasal dari institusi pemerintah, namun ada juga yang berasal dari institusi swasta. Empat belas (14) aplikasi akuntansi berbasis android ini, memiliki beberapa karakteristik yang berbeda dalam hal output laporan yang dihasilkan, jenis perusahaan yang diperuntukkan dalam penggunaannya, serta fitur laporan yang dihasilkan. Keempat belas aplikasi ini, kemudian diobservasi mengenai output laporan, jenis perusahaan user (dijelaskan dalam web masing-masing), fitur yang ada pada aplikasi tersebut, kemampuan import dalam bentuk excel, kemudian storage atau bentuk penyimpanan. Berikut disajikan tabel terkait output, jenis perusahaan pengguna dan fitur muncul pada masing-masing aplikasi. 
Tabel 4.2. Output Laporan, Jenis Perusahaan Pengguna, dan Fitur Laporan Aplikasi akuntasi berbasis android untuk UMKM

\begin{tabular}{|c|c|c|c|c|c|c|}
\hline No. & $\begin{array}{l}\text { Nama } \\
\text { Aplikasi }\end{array}$ & $\begin{array}{l}\text { Output } \\
\text { Laporan }\end{array}$ & $\begin{array}{c}\text { Jenis } \\
\text { Perusahaan } \\
\text { yang } \\
\text { Menggunakan } \\
\end{array}$ & Fitur & $\begin{array}{c}\text { Import } \\
\text { Laporan ke } \\
\text { dalam } \\
\text { bentuk excel } \\
\end{array}$ & Storage \\
\hline 1 & $\begin{array}{l}\text { Akuntansi } \\
\text { UKM } \\
\text { WiinFeel }\end{array}$ & $\begin{array}{l}\text { Jurnal, BB, } \\
\text { NS,LR,Neraca, } \\
\text { Data Utang, } \\
\text { Data Piutang, } \\
\text { SPT PPH OP }\end{array}$ & $\begin{array}{l}\text { Usaha dagang, } \\
\text { laundry, } \\
\text { counter pulsa, } \\
\text { pengelolaan } \\
\text { keuangan } \\
\text { keluarga, } \\
\text { koperasi } \\
\text { simpan pinjam, } \\
\text { dan lain-lain }\end{array}$ & $\begin{array}{l}\text { Jurnal harian, quick jurnal, koreksi jurnal, } \\
\text { buku besar, neraca saldo, laporan laba rugi, } \\
\text { neraca, periode berdasarkan tanggal (hari, } \\
\text { bulan, tahun), laporan hutang, laporan } \\
\text { piutang, laporan SPT tahunan, export excel, } \\
\text { Backup\&restore, sync Google drive, } \\
\text { pengingat, responsif, multi user, floating } \\
\text { kalkulator, keamanan untuk mengunci } \\
\text { aplikasi }\end{array}$ & Export Excel & $\begin{array}{l}\text { Gratis, Tanpa } \\
\text { Batasan } \\
\text { Entitas, Multi } \\
\text { User }\end{array}$ \\
\hline 2 & $\begin{array}{l}\text { Lamikro- } \\
\text { Akuntansi } \\
\text { Usaha } \\
\text { Mikro }\end{array}$ & $\begin{array}{l}\text { Entri Jurnal, } \\
\text { LR, Lap Posisi } \\
\text { Keuangan. }\end{array}$ & UKM Mikro & $\begin{array}{l}\text { Entri jurnal, daftar jurnal, laba rugi, dan } \\
\text { neraca }\end{array}$ & $\mathrm{x}$ & $\begin{array}{l}\text { Menggunakan } \\
\text { Internet, data } \\
\text { tersimpan di } \\
\text { aplikasi saat } \\
\text { offline namun } \\
\text { baru bisa } \\
\text { diupdate saat } \\
\text { online, Multi } \\
\text { User }\end{array}$ \\
\hline 3 & $\begin{array}{l}\text { Akuntansi } \\
\text { Keuangan }\end{array}$ & $\begin{array}{l}\text { Jurnal, BB, } \\
\text { NS,LR,Neraca, } \\
\text { Data Utang, } \\
\text { Data Piutang, } \\
\text { SPT PPH OP, } \\
\text { Dll }\end{array}$ & $\begin{array}{l}\text { UKM Mikro, } \\
\text { dan } \\
\text { Perusahaan } \\
\text { setara lainnya }\end{array}$ & $\begin{array}{l}\text { Informasi grafik, pemasukan tunai, } \\
\text { pemasukan piutang, pengeluaran tunai, } \\
\text { pengeluaran hutang, tambah hutang, bayar } \\
\text { hutang, tambah piutang, penyetoran piutang, } \\
\text { tambah modal, tarik modal, pengalihan aset, } \\
\text { set saldo awal, pendapatan diterima dimuka, } \\
\text { dan penyesuaian hutang pendapatan }\end{array}$ & & $\begin{array}{l}\text { Berbayar,Men } \\
\text { ggunakan } \\
\text { Internet, data } \\
\text { tersimpan di } \\
\text { aplikasi saat } \\
\text { offline namun } \\
\text { baru } \\
\text { diupdate baat } \\
\text { online, Multi } \\
\text { User }\end{array}$ \\
\hline 4 & SI APIK & $\begin{array}{l}\text { Laba Rugi, Arus } \\
\text { Kas, Neraca, }\end{array}$ & $\begin{array}{l}\text { Pelaku usaha } \\
\text { mikro }\end{array}$ & $\begin{array}{l}\text { Neraca, Laba Rugi, Arus Kas dan Rincian } \\
\text { Pos Keuangan. Di samping itu, PTK juga }\end{array}$ & Export Excel & $\begin{array}{l}\text { Gratis, Tanpa } \\
\text { Batasan }\end{array}$ \\
\hline
\end{tabular}




\begin{tabular}{|c|c|c|c|c|c|c|}
\hline & & $\begin{array}{l}\text { Solvabilitas, } \\
\text { Likuiditas, } \\
\text { Profabilitas, } \\
\text { Perputaran } \\
\text { Modal Kerja, } \\
\text { Kinerja } \\
\text { Operasional, } \\
\text { Repayment } \\
\text { Capacity, dan } \\
\text { Rincian Pos } \\
\text { Keuangan, }\end{array}$ & $\begin{array}{l}\text { perorangan dan } \\
\text { pelaku usaha } \\
\text { kecil sektor } \\
\text { jasa, } \\
\text { perdagangan, } \\
\text { pertanian, } \\
\text { maupun } \\
\text { manufaktur }\end{array}$ & $\begin{array}{l}\text { dilengkapi dengan laporan kinerja keuangan } \\
\text { mencakup solvabilitas, likuiditas, } \\
\text { profitabilitas, perputaran modal kerja, kinerja } \\
\text { operasional dan repayment capacity dengan } \\
\text { penjelasan yang ringkas dan mudah } \\
\text { dipahami. }\end{array}$ & & $\begin{array}{l}\text { Entitas, } \\
\text { Jumlah } \\
\text { Transaksi, } \\
\text { Periode, } \\
\text { Jumlah } \\
\text { Pemasok, } \\
\text { Jumlah } \\
\text { Barang, serta } \\
\text { Multi User }\end{array}$ \\
\hline 5 & $\begin{array}{l}\text { Pembukuan } \\
\& \\
\text { Akuntansi. } \\
\text { Stock } \\
\text { Barang. } \\
\text { Arus Kas }\end{array}$ & $\begin{array}{l}\text { Catatan } \\
\text { Inventaris, } \\
\text { Revaluasi Stok, } \\
\text { Melakukan } \\
\text { Penyelesaian } \\
\text { Transaksi } \\
\text { Bersama, dll }\end{array}$ & $\begin{array}{l}\text { Semua } \\
\text { kalangan usaha }\end{array}$ & $\begin{array}{l}\text { Menjual atau membeli barang dan jasa (ritel, } \\
\text { grosir, kredit toko, Utang, Uang Tunai), } \\
\text { Menjaga catatan inventaris dan membuat } \\
\text { daftar harga, Membuat dan mendistribusikan } \\
\text { tabel harga ke pelanggan grosir, Menerima } \\
\text { dan membelanjakan uang dalam mata uang } \\
\text { apa pun, Melakukan penyelesaian akhir } \\
\text { transaksi bersama dengan pelanggan, } \\
\text { pemasok, dan mitra lainnya, Mencatat jumlah } \\
\text { inventaris dan melakukan revaluasi stok, } \\
\text { Memindai kode batang dengan kamera } \\
\text { perangkat, Memiliki akun dengan banyak } \\
\text { mata uang pada saat bersamaan, } \\
\text { Memperkirakan pengeluaran dan } \\
\text { profitabilitas, Mencetak dokumen langsung } \\
\text { dari aplikasi }\end{array}$ & $\mathrm{x}$ & $\begin{array}{l}\text { Berbayar,Men } \\
\text { ggunakan } \\
\text { Internet, data } \\
\text { tersimpan di } \\
\text { aplikasi saat } \\
\text { offline namun } \\
\text { baru bisa } \\
\text { diupdate saat } \\
\text { online, Multi } \\
\text { User }\end{array}$ \\
\hline 6 & $\begin{array}{l}\text { Book } \\
\text { Keeper } \\
\text { Accounting } \\
\text { Invoicing, } \\
\text { Inventory }\end{array}$ & $\begin{array}{l}\text { Laporan } \\
\text { Akuntansi } \\
\text { Keuangan dan } \\
\text { Laporan Rinci } \\
\text { Item }\end{array}$ & $\begin{array}{lr}\text { Pelaku usaha } \\
\text { kecil \& } \\
\text { menengah }\end{array}$ & $\begin{array}{l}\text { Buat akun, inventaris, perusahaan, transaksi } \\
\text { tanpa batas, Faktur: Faktur untuk produk dan } \\
\text { layanan; Kustomisasi bidang faktur seperti } \\
\text { jumlah, tarif, jumlah kata, detail } \\
\text { pengiriman; Tambahkan logo perusahaan ke } \\
\text { faktur; Tanda tangani faktur Anda; Kirim } \\
\text { faktur melalui email / WhatsApp atau ambil } \\
\text { cetakan; Lacak faktur berbayar \& terutang, } \\
\text { Perkiraan: Buat dan kirim taksiran ke }\end{array}$ & Export Excel & $\begin{array}{l}\text { Gratis, Tanpa } \\
\text { Batasan } \\
\text { Entitas, Multi } \\
\text { User }\end{array}$ \\
\hline
\end{tabular}




\begin{tabular}{|c|c|c|c|c|c|c|}
\hline & & & & $\begin{array}{l}\text { pelanggan Anda, konversikan ke faktur nanti, } \\
\text { Pengeluaran / Penerimaan: Masukkan biaya } \\
\text { bisnis; pembayaran dilakukan; penghasilan } \\
\text { yang diperoleh; menganalisis laba yang } \\
\text { diperoleh, Manajemen Persediaan: Kelola } \\
\text { seluruh inventaris Anda di berbagai gudang, } \\
\text { Laporan keuangan: Analisis mendalam bisnis } \\
\text { Anda dengan 30+ laporan komprehensif, } \\
\text { Tidak diperlukan koneksi internet: Aplikasi / } \\
\text { perangkat lunak akuntansi offline, kelola } \\
\text { akun saat bepergian, Aplikasi yang berdiri } \\
\text { sendiri: Memelihara buku-buku akuntansi } \\
\text { keuangan, tidak ada ketergantungan pada } \\
\text { perangkat lunak lain, tidak perlu mendaftar, } \\
\text { Tidak ada pengetahuan akuntansi } \\
\text { sebelumnya: Memelihara buku akuntansi } \\
\text { dengan mudah, tidak diperlukan pengetahuan } \\
\text { akuntansi / pembukuan, Sinkronisasi Online: } \\
\text { Sinkronkan data perusahaan Anda di } \\
\text { beberapa perangkat melalui Dropbox.Semua } \\
\text { data yang dimasukkan pada satu perangkat } \\
\text { tercermin pada perangkat lain pada saat yang } \\
\text { bersamaan, Banyak Pengguna: Anda dapat } \\
\text { berkolaborasi dengan karyawan dan akuntan } \\
\text { Anda. Beberapa pengguna berkolaborasi di } \\
\text { perusahaan yang sama dengan akses berbasis } \\
\text { peran }\end{array}$ & & \\
\hline 7 & 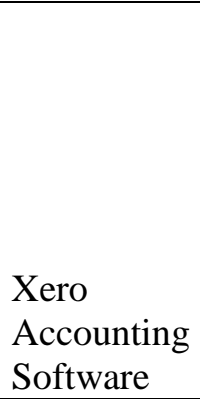 & $\begin{array}{l}\text { Pembukuan, } \\
\text { Proses Faktur, } \\
\text { Catatan Tagihan } \\
\text { dan Rekonsiliasi } \\
\text { Bank }\end{array}$ & $\begin{array}{l}\text { Pelaku usaha } \\
\text { kecil }\end{array}$ & $\begin{array}{l}\text { Visibilitas semua rekening bank, kartu kredit } \\
\text { dan saldo PayPal, tagihan luar biasa, klaim } \\
\text { biaya, tagihan untuk membayar, laporan, dan } \\
\text { kontak, Rekonsiliasi pernyataan bank super } \\
\text { cepat, Buat menyetujui dan kirim faktur } \\
\text { langsung dari perangkat Android, Tetap di } \\
\text { atas uang yang keluar,Tambahkan dan setujui } \\
\text { tagihan atau catat penerimaan di tempat } \\
\text { bekerja dari mana saja, Panggil pelanggan }\end{array}$ & $\mathrm{X}$ & $\begin{array}{l}\text { Gratis, Tanpa } \\
\text { Batasan } \\
\text { Entitas, Multi } \\
\text { User }\end{array}$ \\
\hline
\end{tabular}




\begin{tabular}{|c|c|c|c|c|c|c|}
\hline & & & & $\begin{array}{l}\text { dan pemasok langsung dari aplikasi (temukan } \\
\text { mereka di peta juga) dan kemudian simpan } \\
\text { semua catatan yang diperlukan langsung } \\
\text { kembali ke Xero, Pembukuan menjadi } \\
\text { mudah, serta dapatkan semua yang } \\
\text { dibutuhkan untuk mengelola dan melacak } \\
\text { penjualan dan pengeluaran }\end{array}$ & & \\
\hline 8 & $\begin{array}{l}\text { Akuntansi } \\
\text { Dagang - } \\
\text { Beta }\end{array}$ & $\begin{array}{l}\text { Laporan } \\
\text { Akuntansi } \\
\text { Keuangan dan } \\
\text { Laporan Rinci } \\
\text { Item }\end{array}$ & UKM & $\begin{array}{l}\text { Tersedianya informasi buku piutang dan } \\
\text { hutang, Adanya daftar Pelanggan dan } \\
\text { Supplier untuk memudahkan pencatatan, } \\
\text { Buku Persediaan yang secara realtime dapat } \\
\text { dilihat karena menggunakan metode } \\
\text { perpetual, Generate laporan keuangan secara } \\
\text { instan, dan lain-lain }\end{array}$ & $\mathrm{x}$ & $\begin{array}{l}\text { Gratis, Tanpa } \\
\text { Batasan } \\
\text { Entitas, Multi } \\
\text { User }\end{array}$ \\
\hline 9 & $\begin{array}{l}\text { Zahir } \\
\text { Simply }\end{array}$ & $\begin{array}{l}\text { Laporan } \\
\text { Akuntansi } \\
\text { Keuangan dan } \\
\text { Laporan Rinci } \\
\text { Item }\end{array}$ & UKM & $\begin{array}{l}\text { User Friendly: Tampilan menarik, sederhana } \\
\text { dan mudah dipahami. tidak perlu mengerti } \\
\text { akuntansi, Anda sudah bisa membuat } \\
\text { Laporan Keuangan secara realtime, } \\
\text { Dashboard: Membantu Anda melihat omset } \\
\text { penjualan, biaya sampai keuntungan bisnis } \\
\text { Anda secara realtime. Informasi dasbor } \\
\text { bermanfaat untuk Anda dalam menentukan } \\
\text { strategi dan keputusan bisnis secara cepat, } \\
\text { Sales and Invoice : Membantu Anda } \\
\text { mencatat penjualan serta memberikan } \\
\text { informasi penjualan, mulai dari status } \\
\text { penjualan kredit, jatuh tempo hingga } \\
\text { penjualan yang sudah lunas, Purchase : } \\
\text { Membantu Anda mencatat pembelian serta } \\
\text { memberikan informasi pembelian, mulai dari } \\
\text { status pembelian kredit, jatuh tempo hingga } \\
\text { pembelian yang sudah lunas, Vendor } \\
\text { Payment : Pembayaran kepada pemasok, } \\
\text { sehingga tidak ada lagi tagihan yang } \\
\text { berantakan dan tidak termonitor dengan jelas, } \\
\text { Customer Payment : Membantu Anda untuk }\end{array}$ & $\mathrm{x}$ & $\begin{array}{l}\text { Gratis, Tanpa } \\
\text { Batasan } \\
\text { Entitas, Multi } \\
\text { User }\end{array}$ \\
\hline
\end{tabular}




\begin{tabular}{|c|c|c|c|c|c|c|c|}
\hline & & & & $\begin{array}{l}\text { mencatat penerimaan pelunasan dari } \\
\text { pelanggan, Expense : Membantu anda untuk } \\
\text { mencatat semua biaya. biaya yang } \\
\text { dikeluarkan dan tercatat dengan baik akan } \\
\text { membantu anda mengatur dan mengelola } \\
\text { keuangan bisnis Anda agar bisa lebih } \\
\text { terkontrol. }\end{array}$ & & & \\
\hline 10 & $\begin{array}{l}\text { Grow - } \\
\text { Akuntansi } \\
\& \\
\text { Keuangan } \\
\text { UKM }\end{array}$ & $\begin{array}{l}\text { Laporan } \\
\text { Akuntansi } \\
\text { Keuangan dan } \\
\text { Laporan Rinci } \\
\text { Item }\end{array}$ & UKM & $\begin{array}{l}\text { Buat, edit, hapus, hingga kirim invoice } \\
\text { langsung kepada client kapan saja dan } \\
\text { dimana saja, Kelola stok barang antar gudang } \\
\text { hingga stock opname dengan mudah, akurat, } \\
\text { dan real-time, Mudahkan komunikasi melalui } \\
\text { kirim SMS atau telpon client dengan } \\
\text { database kontak client yang rapi, Pantau } \\
\text { laporan untung/rugi, status invoice dan } \\
\text { piutang, dan saldo kas dan bank dalam satu } \\
\text { klik }\end{array}$ & $\mathrm{X}$ & $\begin{array}{l}\text { Gratis, } \\
\text { Batasan } \\
\text { Entitas, } \\
\text { User }\end{array}$ & $\begin{array}{l}\text { Tanpa } \\
\text { Multi }\end{array}$ \\
\hline 11 & $\begin{array}{l}\text { Accounting } \\
\text { Invoicing - } \\
\text { OneUp }\end{array}$ & $\begin{array}{l}\text { Catatan } \\
\text { Inventaris, } \\
\text { Revaluasi Stok, } \\
\text { Laporan } \\
\text { Akuntansi } \\
\text { Keuangan dan } \\
\text { Laporan Rinci } \\
\text { Item }\end{array}$ & $\begin{array}{l}\text { Semua } \\
\text { kalangan usaha }\end{array}$ & $\begin{array}{l}\text { Usaha Penagihan, Pembukuan Automatic, } \\
\text { Tutup Sales More, Time Akuntansi, } \\
\text { Pengendalian Pengeluaran Anda, Inventory } \\
\text { Automatic, Manajemen Rantai Pasokan } \\
\text { Otomatis, dan Fleksibel Pajak }\end{array}$ & $\mathrm{X}$ & $\begin{array}{l}\text { Gratis, } \\
\text { Batasan } \\
\text { Entitas, } \\
\text { User }\end{array}$ & $\begin{array}{l}\text { Tanpa } \\
\text { Multi }\end{array}$ \\
\hline 12 & $\begin{array}{l}\text { Free GST } \\
\text { Invoice } \\
\text { Billing } \\
\text { Stock } \\
\text { Inventory } \\
\text { Accounts }\end{array}$ & $\begin{array}{l}\text { Faktur Gratis, } \\
\text { Penagihan, } \\
\text { Inventaris, } \\
\text { Laporan GST, } \\
\text { Akuntansi } \\
\text { Bisnis, } \\
\text { Pembukuan }\end{array}$ & $\begin{array}{l}\text { Semua } \\
\text { kalangan usaha }\end{array}$ & $\begin{array}{l}\text { Mengaktifkan Faktur dan Penagihan Gratis. } \\
\text { Buat faktur dalam format faktur. membuat } \\
\text { Faktur, Perkiraan, Challans Pengiriman, } \\
\text { Pesanan Pembelian \& Pesanan Penjualan, } \\
\text { semuanya dari satu aplikasi.Kelola inventaris } \\
\text { stok Anda - (Stok dalam aplikasi keluar), } \\
\text { Periksa laporan pengeluaran \& lacak } \\
\text { pengeluaran bisnis, Lacak laporan seperti } \\
\text { penjualan, pembelian \& laporan pendapatan, } \\
\text { Dapatkan Buku Hari, laporan Penghasilan \& } \\
\text { semua laporan GST untuk mengetahui status }\end{array}$ & $\mathrm{X}$ & $\begin{array}{l}\text { Gratis, } \\
\text { Batasan } \\
\text { Entitas, } \\
\text { User }\end{array}$ & Tanpa \\
\hline
\end{tabular}




\begin{tabular}{|c|c|c|c|c|c|c|}
\hline & & & & $\begin{array}{l}\text { bisnis, Ketahui keuntungan \& kerugian, \& } \\
\text { ambil keputusan yang tepat. }\end{array}$ & & \\
\hline 13 & $\begin{array}{l}\text { Catatan } \\
\text { Keuangan } \\
\text { Usaha }\end{array}$ & $\begin{array}{l}\text { Menghitung dan } \\
\text { Mencatat } \\
\text { Pendapatan } \\
\text { Usaha, Biaya } \\
\text { Usaha, Modal } \\
\text { Usaha, Laporan } \\
\text { Usaha, dan } \\
\text { Laporan Laba } \\
\text { Rugi }\end{array}$ & $\begin{array}{l}\text { Pelaku usaha } \\
\text { kecil \& } \\
\text { menengah }\end{array}$ & $\begin{array}{l}\text { Menghitung pencatatan biaya usaha, } \\
\text { Menghitung pencatatan modal usaha, } \\
\text { Membuat laporan untung } \\
\text { Menghasilkan laporan keuangan, Download } \\
\text { laporan usaha dalam format PDF, dan data } \\
\text { disimpan di server. }\end{array}$ & $\mathrm{x}$ & $\begin{array}{l}\text { Gratis, } \\
\text { Menggunakan } \\
\text { Internet dan } \\
\text { Multi User }\end{array}$ \\
\hline 14 & $\begin{array}{l}\text { Pencatat } \\
\text { Keuangan }\end{array}$ & $\begin{array}{l}\text { Catatan } \\
\text { Inventaris, } \\
\text { Revaluasi Stok, } \\
\text { Melakukan } \\
\text { Penyelesaian } \\
\text { Transaksi } \\
\text { Bersama, dan } \\
\text { Menghitung dan } \\
\text { Mencatat } \\
\text { Pendapatan } \\
\text { Usaha, Biaya } \\
\text { Usaha }\end{array}$ & $\begin{array}{l}\text { Pelaku usaha } \\
\text { mikro } \\
\text { perorangan }\end{array}$ & $\begin{array}{l}\text { Pencatatan Pemasukan, Pencatatan } \\
\text { Pengeluaran, Cek saldo, Melihat riwayat } \\
\text { transaksi, dan Export riwayat transaksi ke csv } \\
\text { file }\end{array}$ & $\mathrm{x}$ & $\begin{array}{l}\text { Gratis, Tanpa } \\
\text { Batasan } \\
\text { Entitas, Multi } \\
\text { User }\end{array}$ \\
\hline
\end{tabular}

Sumber: diolah dari berbagai sumber 


\subsection{Profil UMKM Potensial Pengguna berdasarkan IFLS Data}

Survei IFLS 5 pada tahun 2015 dilakukan pada 15.921 rumah tangga yang terletak di 13 provinsi di Indonesia. Berdasarkan pada data tersebut terdapat 5.759 rumah tangga yang memiliki usaha non pertanian yang akan menjadi objek penelitian. Pertanyaan pada buku 2 survei IFLS ditanyakan mengenai penggunaan internet dan hape dalam proses usaha. Pada proses ini, dari 5.759 HHID tersisa hanya 577 HHID atau rumah tangga yang menggunakan handphone dan internet dalam kegiatan usahanya. Dan berdasarkan hasil ini, didapat hasil sebagai berikut:

Tabel 4.3. Bidang Lapangan Usaha

\begin{tabular}{|c|c|c|c|}
\hline bussines? & Freq. & Percent & Cum. \\
\hline 1: Agriculture & 8 & 1.39 & 1.39 \\
\hline 2:Sales & 4 & 0.69 & 2.08 \\
\hline $4:$ Electricity & 6 & 1.04 & 3.12 \\
\hline 5 : Construction & 15 & 2.60 & 5.72 \\
\hline 7 :Transportation and communication & 15 & 2.60 & 8.32 \\
\hline $8:$ Finance & 19 & 3.29 & 11.61 \\
\hline 21 : Restaurant & 42 & 7.28 & 18.89 \\
\hline 22: Industrial: food & 21 & 3.64 & 22.53 \\
\hline 23:Industrial: garment & 23 & 3.99 & 26.52 \\
\hline 24: Industrial: other & 18 & 3.12 & 29.64 \\
\hline 25: Store: outside of food & 210 & 36.40 & 66.03 \\
\hline 32: Service: Teacher & 6 & 1.04 & 67.07 \\
\hline 33:Service: Proffesional staff & 77 & 13.34 & 80.42 \\
\hline 34:Service: Transportation & 8 & 1.39 & 81.80 \\
\hline 35: Service: Other & 66 & 11.44 & 93.24 \\
\hline 95:Other & 39 & 6.76 & 100.00 \\
\hline Total & 577 & 100.00 & \\
\hline
\end{tabular}

Sumber: diolah dari data IFLS

Pada tabel di atas, diperoleh hasil terbesar usaha yang familiar dalam penggunaan internet dan hape dalam proses usahanya yaitu jenis usaha penjualan (non makanan) yaitu sebesar $36,40 \%$, sedangkan jenis usaha kedua terbesar adalah jenis usaha servis (staf profesional) sebesar 13,34\%, dan ketiga adalah jenis usaha servis lain-lain. 
Tabel 4.4. Profil UMKM berdasarkan Jumlah pekerja

\begin{tabular}{|c|c|c|c|}
\hline $\begin{array}{r}\text { How many } \\
\text { paid } \\
\text { workers, } \\
\text { worked for } \\
\text { this } \\
\text { business in } \\
\text { the last } \\
\text { four weeks? }\end{array}$ & Freq. & Percent & Cum. \\
\hline 0 & 308 & 55.00 & 55.00 \\
\hline 1 & 78 & 13.93 & 68.93 \\
\hline 2 & 61 & 10.89 & 79.82 \\
\hline 3 & 22 & 3.93 & 83.75 \\
\hline 4 & 22 & 3.93 & 87.68 \\
\hline 5 & 16 & 2.86 & 90.54 \\
\hline 6 & 8 & 1.43 & 91.96 \\
\hline 7 & 3 & 0.54 & 92.50 \\
\hline 8 & 5 & 0.89 & 93.39 \\
\hline 10 & 7 & 1.25 & 94.64 \\
\hline 12 & 3 & 0.54 & 95.18 \\
\hline 13 & 1 & 0.18 & 95.36 \\
\hline 14 & 1 & 0.18 & 95.54 \\
\hline 15 & 8 & 1.43 & 96.96 \\
\hline 17 & 2 & 0.36 & 97.32 \\
\hline 18 & 3 & 0.54 & 97.86 \\
\hline 20 & 2 & 0.36 & 98.21 \\
\hline 21 & 1 & 0.18 & 98.39 \\
\hline 25 & 4 & 0.71 & 99.11 \\
\hline 30 & 2 & 0.36 & 99.46 \\
\hline 35 & 1 & 0.18 & 99.64 \\
\hline 42 & 1 & 0.18 & 99.82 \\
\hline 120 & 1 & 0.18 & 100.00 \\
\hline Total & 560 & 100.00 & \\
\hline
\end{tabular}

Sumber: diolah dari data IFLS

Sedangkan berdasarkan jumlah pekerja yang dipekerjakan, kebanyakan UMKM tidak memiliki pekerja yang diupah yaitu sebanyak 55\%. Sedangkan berdasarkan profil usia, UMKM yang familiar penggunaan handphone dan internet kebanyakan dijalankan oleh ART dengan usia 14-30 tahun, yaitu sebesar 56,09\%.

Tabel 4.5. Profil UMKM berdasarkan Usia Pelaku UMKM

\begin{tabular}{|l|r|r|}
\hline Usia & Jumlah & Persentase \\
\hline $14-30$ & 276 & 56,09756 \\
\hline $31-49$ & 185 & 37,60163 \\
\hline$>50$ & 31 & 6,300813 \\
\hline
\end{tabular}

\section{Kesimpulan, Implikasi dan Keterbatasan Penelitian}

Berdasarkan hasil observasi pada penelitian ini, terdapat 14 aplikasi akuntansi berbasis android yang bisa digunakan oleh UMKM dalam membantu pembuatan laporan keuangannya. Keempat belas (14) aplikasi tersebut, memiliki karakteristik yang berbeda dan output atau luaran yang berbeda. Sedangkan berdasarkan survei IFLS 5 pada tahun 2015 yang dilakukan pada 15.921 rumah tangga, yang terletak di 13 provinsi di Indonesia. Pada tabel di atas, diperoleh hasil terbesar usaha yang familiar dalam 
penggunaan internet dan handphone dalam proses usahanya yaitu jenis usaha penjualan (non makanan) yaitu sebesar $36,40 \%$, sedangkan jenis usaha kedua terbesar adalah jenis usaha servis (staf profesional) sebesar 13,34\%, dan ketiga adalah jenis usaha servis lain-lain. Sedangkan berdasarkan profil usia, UMKM yang familiar penggunaan handphone dan internet kebanyakan dijalankan oleh ART dengan usia 14-30 tahun, yaitu sebesar 56,09\%. Penelitian ini hanya merupakan fase awal dalam proses penelitian terhadap aplikasi akuntansi yang beredar di masyarakat dan memberikan gambaran mengenai pengguna aplikasi akuntansi secara umum. Dalam penelitian selanjutnya hendaknya dibahas mengenai implementasi aplikasi ini pada UMKM secara langsung.

\section{Daftar Pustaka}

Anggraeni, B. D. (2016). Pengaruh tingkat literasi keuangan pemilik usaha terhadap pengeloaan keuangan. Studi kasus: UMKM Depok. . 4(1).

Anitasari, N. (2017, Agustus 10). https://zahiraccounting.com. Diambil kembali dari https://zahiraccounting.com/id/blog/software-akuntansi-cloud-dan-desktop/

Asosiasi Penyelenggara Jasa Internet Indonesia. (2018). Diambil kembali dari https://apjii.or.id/content/read/39/342/Hasil-Survei-Penetrasi-dan-Perilaku-Pengguna-InternetIndonesia-2017.

Badan Pusat Statistik. (2017, Mei 24). Hasil Pendaftaran (Listing) Usaha/Perusahaan Sensus Ekonomi 2016. Diambil kembali dari bps.go.id: https://purwakartakab.bps.go.id/pressrelease/2017/08/02/87/hasil-pendaftaran--listing--usahaperusahaan-sensus-ekonomi-2016--hasil-pendaftaran-sensus-ekonomi-2016--se2016--jawa-barattercatat-sebanyak-4-63-juta--usaha-perusahaan--non-pertanian-provinsi-ja

Bank Indonesia. (2015). Profil bisnis usaha mikro, kecil dan menengah (UMKM). Lembaga Pengembangan Perbankan Indonesia (LPPI).

Burger, N. a. (2015). Reforming Policies for Small and Medium-Sized Enterprises in Indonesia. RAND Corporation.

databooks. (t.thn.). Dipetik 09 12, 2019, dari https://databoks.katadata.co.id/datapublish/2017/08/29/pengguna-ponsel-indonesia-mencapai142-dari-populasi

Hatta, M. \&. (2013). Kecemasan dalam Penggunaan Software Akuntansi dari Perspektif Gender dan Pengaruhnya terhadap Keahlian Pemakai dengan Locus Of Control sebagai Variabel Moderasi. XVI(4067).

Ikatan Akuntan Indonesia. (2016). Standar Akuntansi Keuangan Entitas Mikro, Kecil dan Menengah (SAK EMKM). Jakarta. 
63 | Irena Paramita Pramono, et al

Kementerian Koperasi dan UKM. (2008). https://www.bi.go.id/. Diambil kembali dari https://www.bi.go.id/id/tentang-bi/uu-bi/Documents/UU20Tahun2008UMKM.pdf.

Komara, A. \&. (2013). Analisis faktor-faktor yang mempengaruhi kinerja sistem informasi akuntansi. . $2(1)$.

Narsa, I. M. (2012). Mengungkap kesiapan UMKM dalam implementasi standar akuntansi keuangan entitas tanpa akuntabilitas publik (PSAK-ETAP) untuk meningkatkan akses modal perbankan. . $22(3)$.

Rudiantoro, R. \&. (2012). Kualitas laporan keuangan umkm serta prospek implementasi SAK ETAP. . $9(1)(1-21)$. 